\title{
The wear resistance research of the rail contact surface depending on the grinding process
}

\author{
Mykola Bobyr $^{1} \bullet$ Yurii Borodii $^{1} \bullet$ Pavlo Protsenko $^{1} \bullet$ Eckart Uhlmann² $\bullet$ Janis Thalau $^{2} \bullet$ Pavlo Lypovka $^{2}$ \\ 1 - Igor Sikorsky Kyiv Polytechnic Institute, Kyiv, Ukraine; \\ 2 - Technology, Institute for Machine Tools and Factory Management (IWF), Technische Universität Berlin, \\ Berlin, Germany
}

Received: 17 September 2019 / Accepted: 27 September 2019

\begin{abstract}
Background. Continuous mechanical loads on the rails during its contact with the wheel lead to an accumulation of residual stresses in the surface layers of the rails, resulting in fast-growing fatigue cracks. In addition, the interaction of the wheel and the rail leads to micro-and macro-slip during their contact, abrasive wear, as well as plastic deformation of the rail. Rail grinding is the repair method by which defective material layers removes from the rail surface, provides the necessary accuracy of size and shape as well as surface quality.

Objective. The aim of the work is to determine the effect of grinding on the tribological properties of the rail surface and establish the optimal parameters of the grinding process to ensure the best wear resistance of the rail surface.

Methods. The research on wear and contact damage of samples of surfaces cut from grinding rails conducted on a friction machine $M-22 M$. The studies were carried out by dry friction of a sample (cut from a rail) with a counter-sample from the material used in the manufacture of railway wheels, for 1 hour, the friction path was $3.60 \mathrm{~km}$. Samples were weighed on a VLR-200 balance before and after the study was performed on the friction machine. As a result, the mass wear value was determined for each sample.

Results. Based on the results of tribological studies, we obtained graphical dependencies of the wear intensity on the hardness of surfaces of samples and histograms which showing the effect of grinding process parameters on the amount of the wear intensity of samples. In the work was investigated influence the next main parameters of the grinding process on wear resistance there are the temperature of the rail, depth of cut, grinding wheel speed.

The results of the work can find practical application in railway transport when repairing rails by grinding.

Conclusions. Based on the analysis of experimental data, the empirical relationship revealed between the depth of cut, the surface hardness of the sample and the intensity of its wear. The nature of the influence of grinding process parameters (rail temperature, depth of cut, grinding wheel speed) on the wear resistance of the rail surface is established. The most optimal values of the process parameters that provide greater wear resistance of the rail surface are depth of cut $-0.007 \mathrm{~mm}$, grinding wheel speed - $30 \mathrm{~m} / \mathrm{s}$, rail temperature $-20^{\circ} \mathrm{C}$ (it is better to conduct the processing of rails in the warm season). The results of the work can find practical application in railway transport when repairing rails by grinding.

Keywords: rail grinding; wear intensity; surface hardening; tribological properties.
\end{abstract}

\section{Introduction}

Currently, there is a constant increase in the speed of rail transport, the relative movements of friction surfaces as well as an increase in specific loads and the presence of abrasive (sand). The most important factor in the rail travel cost optimization is the use of resource-saving technologies that extend inter-repair period and reduce the complexity of current track retention. Therefore, there is a need for new treating methods, working surfaces hardening and technologies to restore the geometrical parameters of the worn out parts. In addition, it is necessary to develop technologies for extending the service life of railway vehicles rails and wheels, including necessary equipment and machinery.

The problem is also complicated the large size of the structural elements, for example, worn out rail surfaces reach tens of meters. This complicates quality assurance and control, and possible manual processing does not provide sufficient productivity and quality.

Continuous mechanical loads on the rails during operation lead to an accumulation of residual stresses in the surface layers of the rails, resulting in fast-growing fatigue cracks. In addition, the interaction of the wheel and the rail leads to micro- and macro-slip, abrasive wear as well as plastic deformation of the rail. The repair of rail defects can do by the grinding. You can positioned the grinding tool at the site of the necessary repair, on the rail surface or edge, thanks to flexible kinematics, where needs removed completely material damaged layers. The tool kinematics and designs selected depending on the requirements for repair. The grinding rails surface roughness should be achieved $R z<25 \mu \mathrm{m}$. Accuracy 
requirements of the rails shape and dimensions are defined by the technical requirements in Ukraine (DSTU4344: 2004) [1], that are being used in manufacturing of rails P50, P65 and P74. In Europe, rails are being manufactured in accordance to the technical requirements EN 13674-1:2011 [2].

Currently, rail grinding is a repair method that allows the removal of defective material layers from the rail surface as well as to provide the necessary accuracy of size and shape. There are a number of papers investigating the technological process of grinding rails, namely: to explore the effects of grinding passes, grinding direction, rotational speed of grinding stone on the material removal behavior of grinding rails during the grinding process [3-5], the grinding effect on surface roughness and hardness of the rail [6], the effects of contact pressure on the abrasive belt grinding performance of rail material [7]. There are few fundamental [3, 8-10] works on the impact of the grinding process and tools on the surface layers of rails, but there is very little fundamental knowledge about the tribological properties and the nature of the use of ground rails. In the work [10] investigated the influence of rails surface roughness on their durability, but the increase of hardness didn't taken into account in the process of grinding of rails. In some articles have researched the optimization of rails grinding in terms of the economy [11] and noise [12]. In the paper [11], based on the management theory of life-cycle cost, the model of analyzing rail grinding parameters is established, the calculation method is determined, grinding factor is optimized from the point of view of minimizing the rail life-cycle cost.

Thus, the aim of the work is to determine the effect of grinding on the tribological properties of the rail surface and establish the optimal parameters of the grinding process to ensure the best wear resistance of the rail surface.

The main tasks set forth in the presented work are:

- Investigation of the effect of various surface hardness achieved by grinding on the wear resistance of rails;

- Optimization of rail grinding parameters based on the results of the effect of rail surface hardness on its wear resistance;

- Creation of a tribological model for determining the nature of the use of grinding rails in real conditions of operation.

\section{Results}

The research was carried out on wear and contact damage of the surfaces of ground rail samples, which were carried out on the friction machine M-22M under the scheme of a roll - square in conditions of dry friction (Fig.1).

As the sample material (Fig. 2), German rail steel was used (HRC 35-38), which was grinding using varying process parameters. The counter-sample (Fig. 3) consist of the steel material, which used in railway wheels and has the hardness HRC 38-40. The tribological tests were carried out with the contact force $-P=100 \mathrm{H}$, the rotational speed $n=490 \mathrm{~min}^{-1}$ resulting in the sliding speed $-1 \mathrm{~m} / \mathrm{s}$ (Fig. 1). The samples were examining on the friction machine M-22 M with dry friction for 1 hour accounting for a friction path $-3.60 \mathrm{~km}$. The rail samples for the tribological tests excised from grinding rails as shown in Fig. 4. The rails were prepared with a rib of the same height prior to grinding to ensure homogeneous grinding conditions.

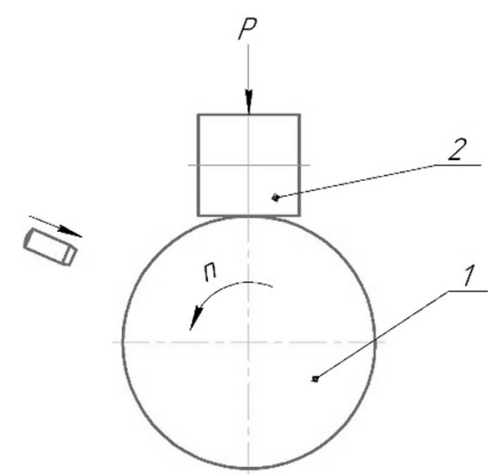

Fig. 1. Test scheme: 1 - countersample, 2 - rail sample

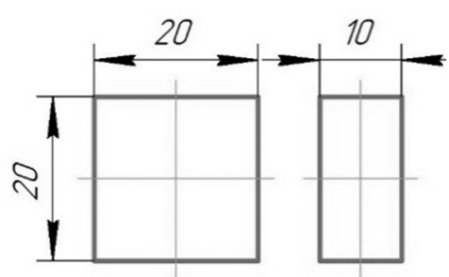

Fig. 2. Rail sample geometry

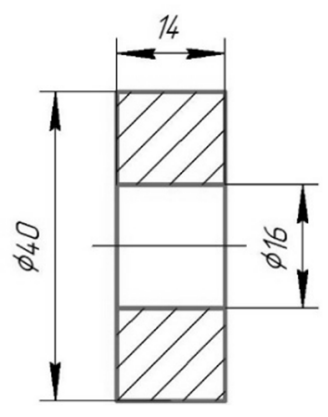

Fig. 3. Counter sample geometry

The laboratory balance of class 2 VLR-200 with a maximum weighing limit of $200 \mathrm{~g}$ and a weighing error of not more than $0.0001 \mathrm{~g}$ (in accordance with GOST 24104-80) used to determine the mass wear of the samples.

In addition to the above shown grinding parameters, different abrasive grain sizes within the grinding wheel (16, 20, $24 \mathrm{Mesh}$ ) as well as varying lubrication conditions were used while grinding. Furthermore, the rail temperature was varied while grinding $\left(-60,-40,-20,0,20,40,60,80^{\circ} \mathrm{C}\right)$ to simulate climatic influences. Next, by plotting the graphical dependencies, an analysis was made of the effect of the indicated parameters on the value of their wear intensity. Fig. 5 shows the wear intensity in dependence of the depth of cut $\mathrm{a}_{\mathrm{e}}$ and the rail hardness while the remaining process parameters remain constant at a temperature of $-20^{\circ} \mathrm{C}$, a feed speed of $v_{f},=22 \mathrm{~m} / \mathrm{min}$ and a grinding speed of $v_{s}=30 \mathrm{~m} / \mathrm{s}$. 


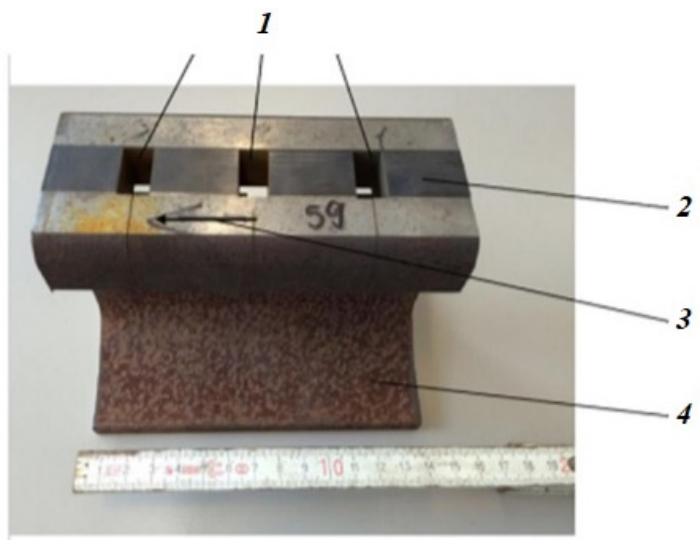

Fig. 4. Ground rail: 1 - sample cutting places; 2 - ground surface; 3 - direction of grinding; 4 - rail foot

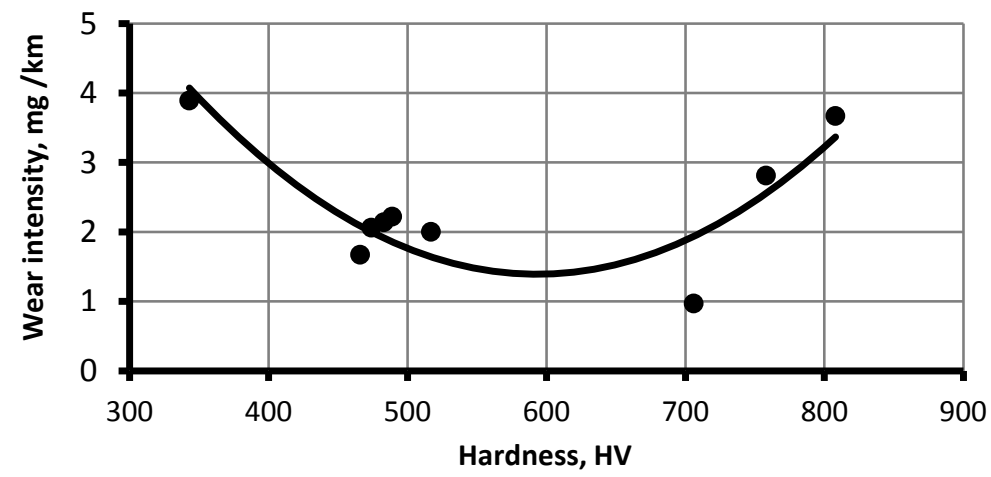

$a$

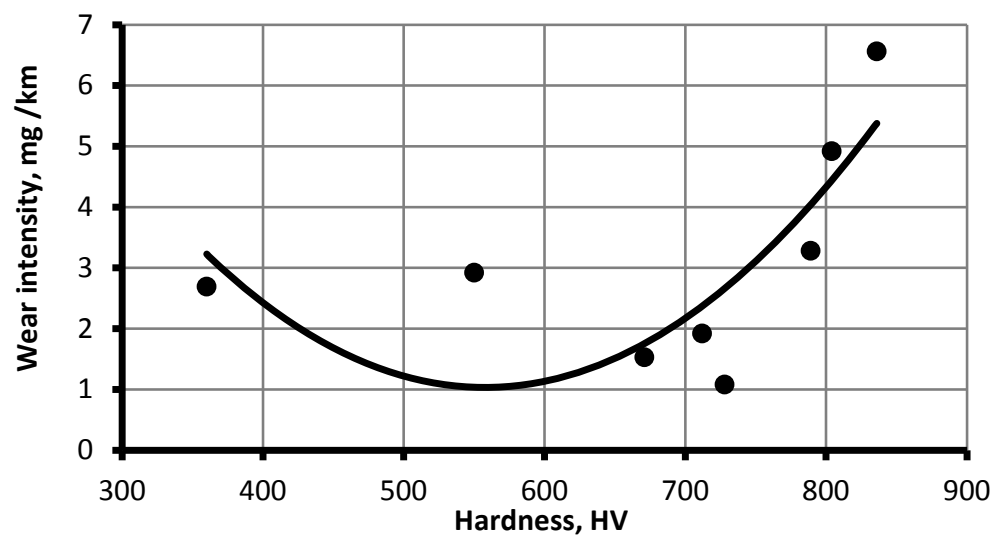

$b$

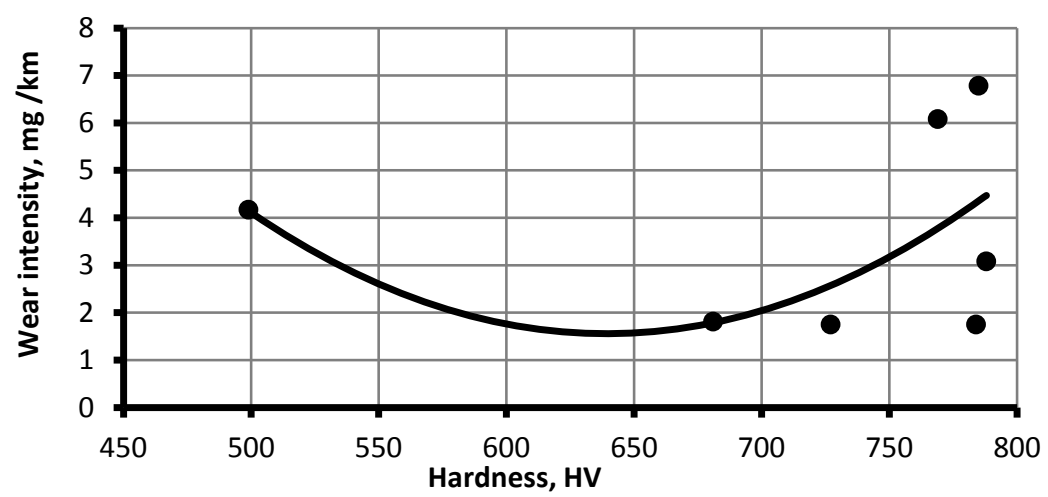

$c$

Fig. 5. Dependence of wear intensity on the value of the sample hardness at different values of the depth of cut $\mathrm{a}$ : $a-0.007 \mathrm{~mm}, b-0.014 \mathrm{~mm}, c-0.021 \mathrm{~mm}$ 
The wear intensity can find using the analytical dependency. Known the work of $V$. Tsybulsky [13], who obtained the analytical dependence to determine the wear intensity of crane wheels based on the work of G. Yampolsky, I. Kragelsky [14], which has the following form:

$$
I_{\kappa}=C \cdot \frac{\varepsilon^{2 / 3} R^{0,5} \sigma_{c . s .}^{2.5-x} \sigma_{c .}^{x} \Delta}{\delta_{w}^{n} \cdot H B_{w}^{1.5} \cdot H B_{r} \sqrt{R_{w}}} \cdot n_{w}
$$

where $C$ is a some constant value; $\varepsilon$ is the concentration of abrasive particles (sand); $R$ is the volumetric radius of the particle; $\sigma_{c . s .}$ is the conditional stress of the compression resistance of an abrasive particle; $\sigma_{c}$ is the contact stress; $\Delta$ is the complex parameter that depends on the size of the tolerance on the wheel size, shape, geometry of the work surface and the accuracy of the wheels; $\delta_{w}$ is the elongation at break of material; $H B_{w}$ and $H B_{r}$ are Brinell hardness, respectively, of wheel and rail materials; $R_{w}$ is the wheel radius; $n_{w}$ is the wheel rotation frequency.

Dependence (1) contains the following factors that affect the wear intensity of a wheel [13]:

1) $A=\varepsilon^{2 / 3} R^{0,5} \sigma_{c . s .}^{2.5-x}-$ influence of the abrasive factor;

2) $P=\frac{\sigma_{c .}^{x}}{\sqrt{R_{w}}} \cdot n_{w}$ - influence of geometric, kinematic characteristics and operating mode;

3) $K=\Delta$ - the impact of machining and assembly quality;

4) $M=\delta_{w}^{n} \cdot H B_{w}^{1.5} \cdot H B_{r}$ - influence of physical and mechanical properties of materials.

In the article [13] dependency obtained and shows in Fig. 6 in accordance to the experimental results, which relates the magnitude of the wear intensity of the crane wheels and the complex parameter $H K_{120}{ }^{3 / 2} \cdot \delta_{5 \mathrm{~B}}{ }^{-2}$ of the deformationstrength properties for the three grades of steels. This is the same as the parameter $M=\delta_{w}^{n} \cdot H B_{w}^{1.5} \cdot H B_{r}$. This parameter has $H K_{120}$ is the Ludwig hardness and $\delta_{5 B}$ is the relative extension. You can calculate them using experimental method assessment of plasticity surfaces of machine parts [15]. Then we decided to compare our results and results from paper [13]. It show on fig.7. For the sake of comparison, all values resulted in a Brinell hardness.

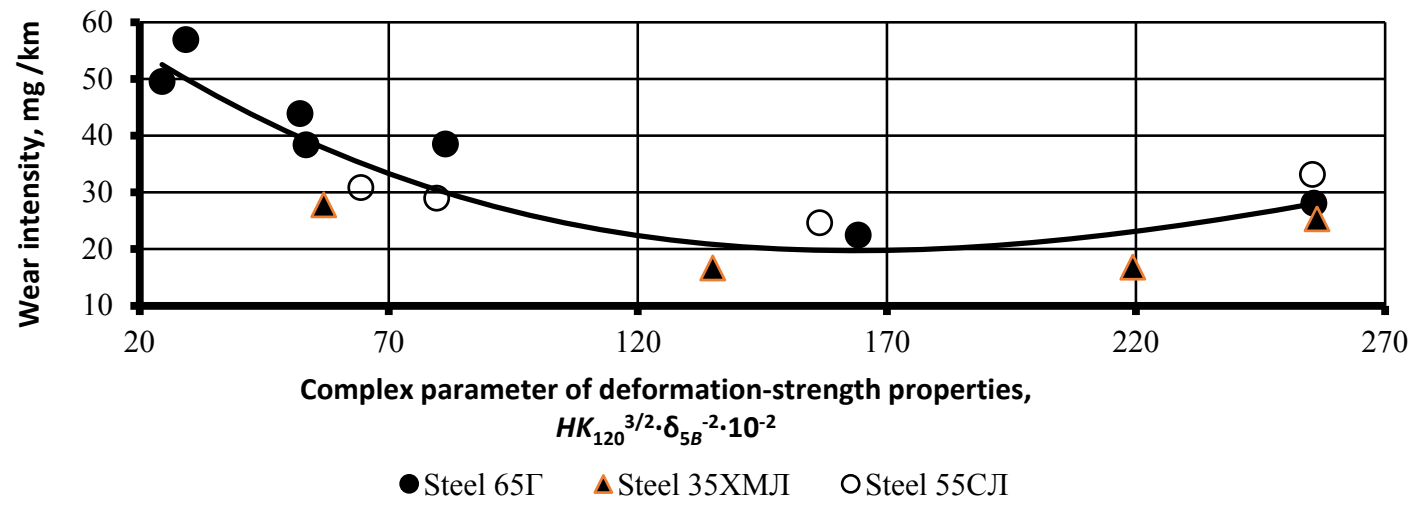

Fig. 6. Dependence of the wear rate on the value of the complex parameter of the deformation-strength properties of materials

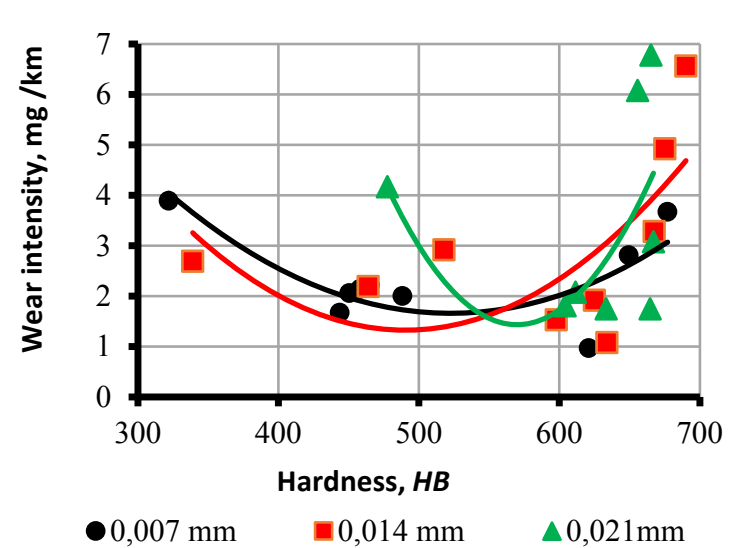

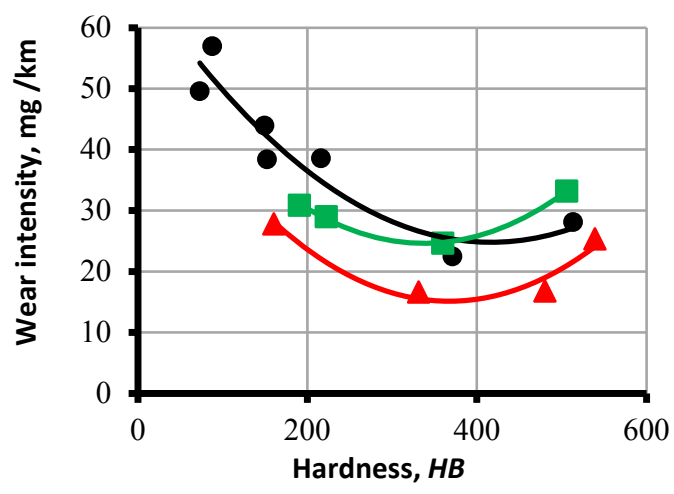

- Steel 65Г $\Delta$ Steel 35ХМЛ $\quad$ - Steel 55СЛ

Fig. 7. Dependences of wear intensity on the value of the samples hardness $(H B): a$ is for rail surface samples, $b$ is for crane wheels from paper [13] 
At work [13], wheel samples tested using a friction machine with the contact force $-P=736 \mathrm{H}$, that is higher than we used $(P=100 \mathrm{H})$. That is why values of the rail samples wear intensity in our tribological tests lower than in results of work [13]. In addition, the rail material and wheel materials are different. The very nature of the dependence of the wear intensity on hardness is similar in both cases (look fig. 7). This confirms the correctness of the results of the experimental studies.

From the above graphs, we can see that the lowest wear intensity occurs for a surface hardness of the samples in the range of $550 \ldots 650 \mathrm{HV}$. The wear intensity for varying grinding depths of cut are shown in Fig. 8 to analyze the influence this parameter on the rail surface hardness.

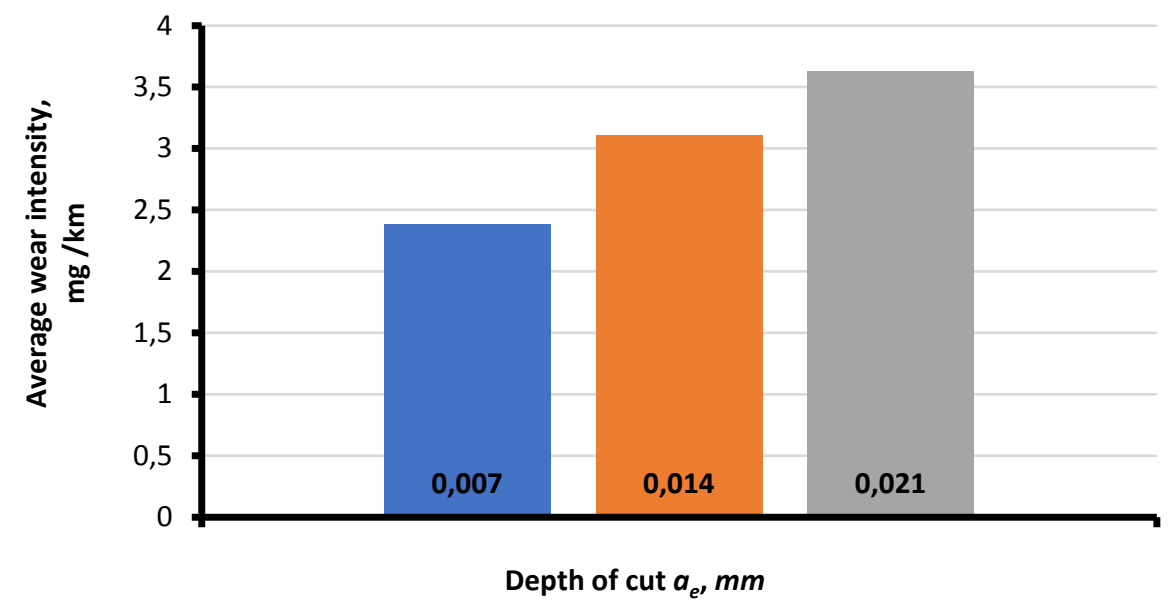

Fig. 8. The dependence of the average wear intensity on the depth of cut

As can be seen from the graphs, a large value of the depth of cut $(0.021 \mathrm{~mm})$ leads to an increase in the average wear intensity by 1.5 times compared with the minimum depth of cut $(0.007 \mathrm{~mm})$. This also confirmed in the work [8].

Since the magnitude of the wear intensity fluctuate with the same grinding surface parameters (depth of cut, rail temperature, grinding wheel speed), it was decided to analyze the effect of the depth of cut on the probable value of the wear intensity. For such the analysis, the dependence of the probability of the normal distribution on the magnitude of the wear intensity was constructed using normal Laplace-Gauss distribution. It described by the next formula [16]:

$$
f(x)=\frac{1}{\sigma \sqrt{2 \pi}} e^{\frac{-(x-\bar{x})^{2}}{2 \sigma^{2}}},
$$

where $\sigma$ is the standard deviation and $\bar{x}$ is the mean or expectation of the distribution. Using the formula (2), we plotted the graphical dependencies in fig. 9. Describes the probability of finding the magnitude of the wear intensity at certain values.

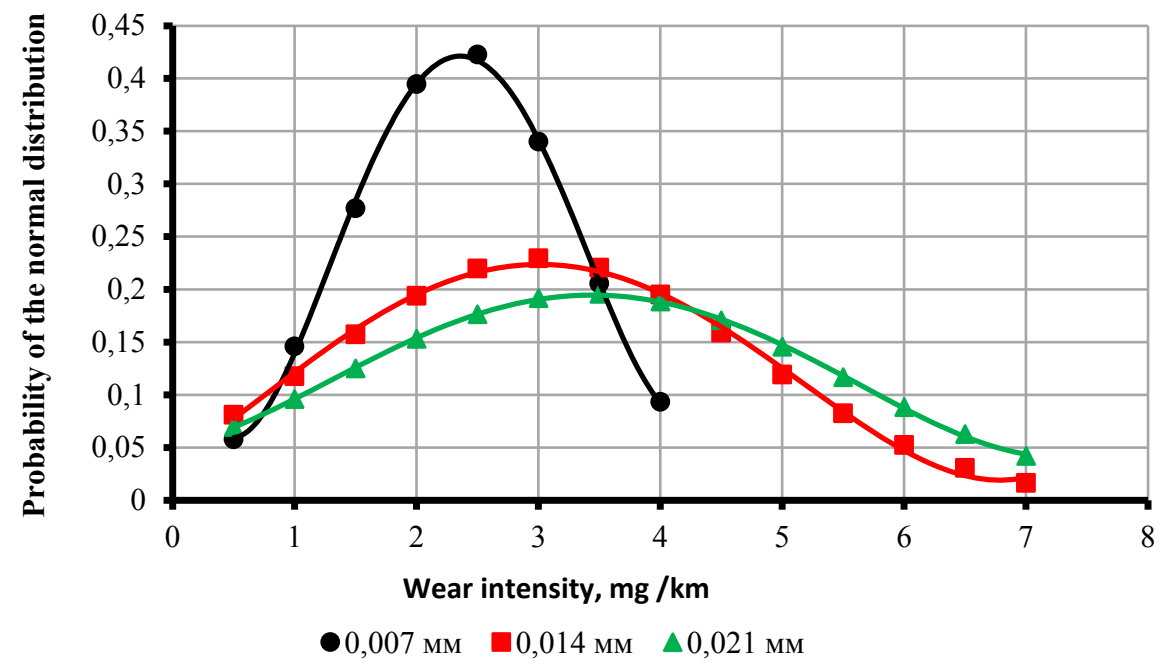

Fig. 9. Probability density function 
As can be seen from fig. 9 the probability density function is narrower and shifts towards lower values of the wear intensity at lower depth of cut values. Therefore, a lower depth of cut value is preferable.

It obtains the empirical dependence of the wear intensity on the surface hardness at different depth of cut values based on the graphs in Fig. 5 and has the next view:

$$
\begin{gathered}
I(H V)=a_{e}^{2}\left((0.884 \cdot H V-642.36)^{2}-15310.37\right)-a_{e}\left((0.1257 \cdot H V-94.35)^{2}-459.82\right)+ \\
+(0.0107 \cdot H V-7.53)^{2}-0.61,
\end{gathered}
$$

where $a_{e}$ is the depth of cut.

For the depth of cut of $a_{e}=0.007 \mathrm{~mm}$, a feed speed of $v_{f}=22 \mathrm{~m} / \mathrm{min}$ and a grinding speed of $v_{\mathrm{s}}=30 \mathrm{~m} / \mathrm{s}$, the effect of varying rail temperature during processing on the amount of wear is analyzed on the basis of the graph shows in Fig. 10.

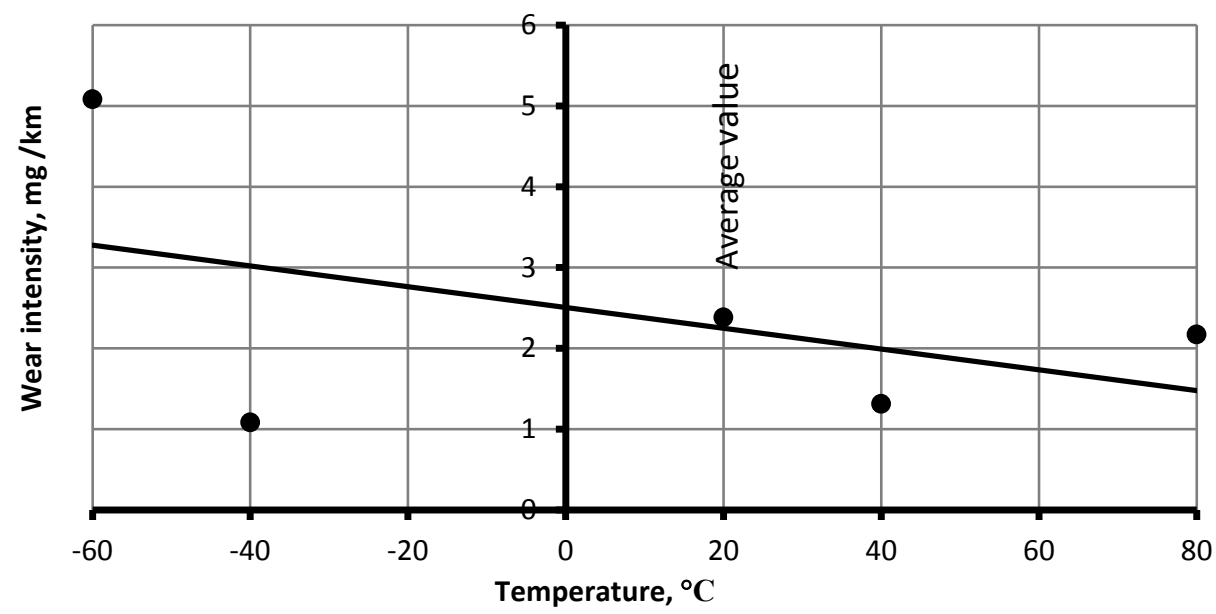

Fig. 10. The dependence of wear intensity on the temperature while grinding with a depth of cut of $a_{e}=0.007 \mathrm{~mm}$

An increase in temperature leads to a decrease in rail the wear intensity and vice versa. A similar pattern can observe at higher depths of cut (Fig. 11).

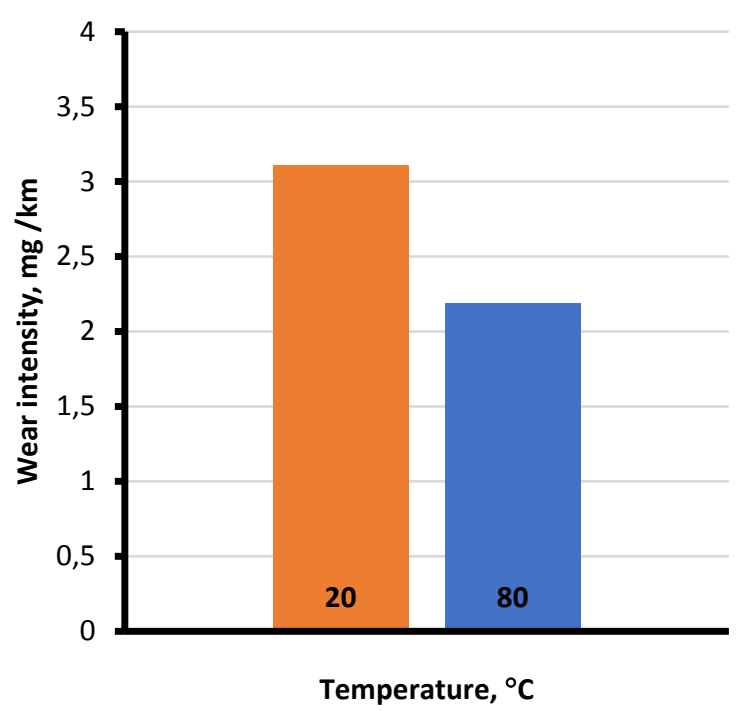

$a$

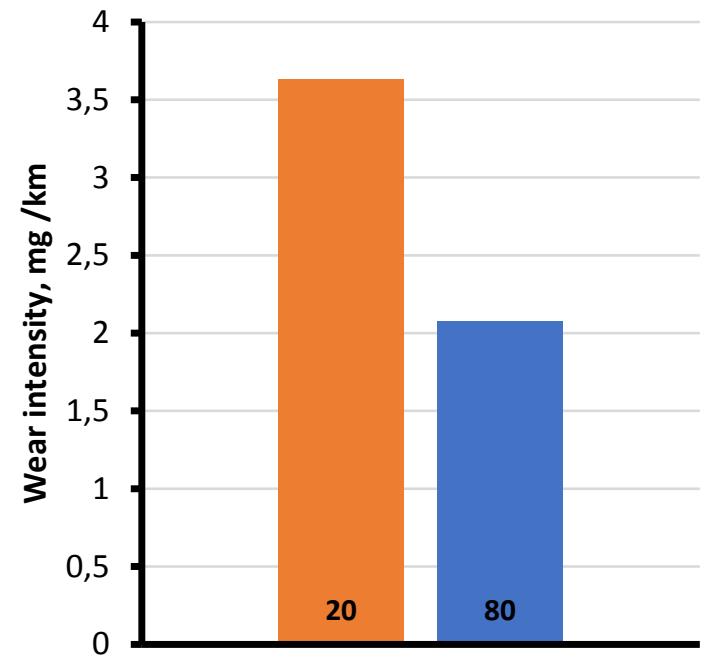

Temperature, ${ }^{\circ} \mathrm{C}$

$b$

Fig. 11. Dependence of wear intensity on the processing temperature of the rails for different depths of cut:

$$
a-0.014 \mathrm{~mm}, b-0.021 \mathrm{~mm}
$$

From fig. 12, it can be seen that for large depths of cut $\left(a_{e}=0.021 \mathrm{~mm}\right)$, there is an influence of the grinding wheel speed on the wear intensity. At lower depths of cut, the effect of grinding speed is minimal. 

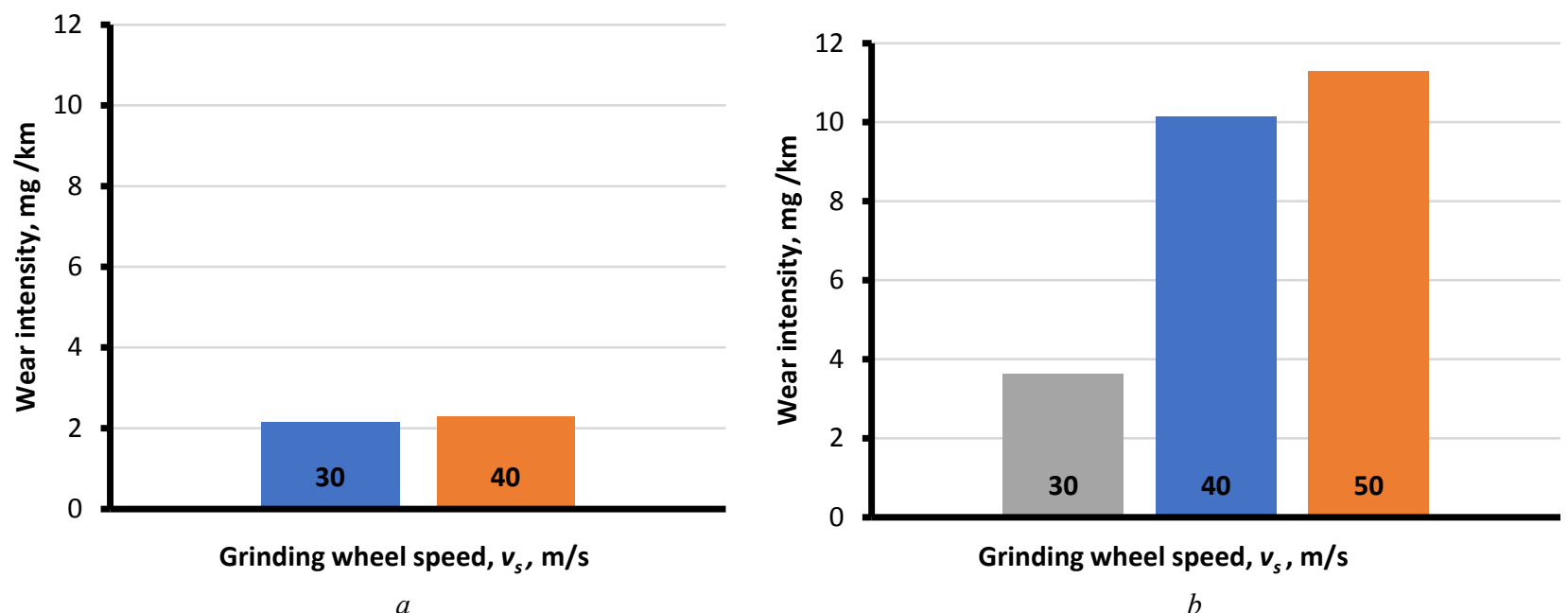

Fig. 12. Influence of the grinding wheel speed on the wear intensity for different depths of cut: $a-0.007 \mathrm{~mm}, b-0.021 \mathrm{~mm}$

From fig. 12, you may see that the more grinding wheel speed leads the more wear intensity.

\section{Conclusion}

1) The influence of the basic technological parameters of the grinding process on the wear resistance of rail samples established through tribological research. These parameters include the grinding temperature, the depth of cut and the grinding wheel speed. The empirical dependence of the wear intensity on the hardness of the rail surface obtained for various depths of cut values.

2) The lowest wear intensity occur for a surface hardness of the samples is in the range of $550 \ldots 650 \mathrm{HV}$.

3) A different character of the dependence of the wear intensity on hardness is noted. For a sample hardness of $300 \ldots 500 \mathrm{HV}$, the wear intensity decreases, with a hardness of $500 \ldots 700 \mathrm{HV}$ it stabilizes and with a hardness of more than $700 \mathrm{HV}$ increases.

4) The dependence of the wear intensity on the hardness for different depths of cut $(0.007 \mathrm{~mm} ; 0.014 \mathrm{~mm}$; $0.021 \mathrm{~mm}$ ) has a similar character: The lowest wear rate occurs for the smallest depth of cut of $a_{e}=0.007 \mathrm{~mm}$. Increasing the grinding depth of cut leads to an increase in the average wear intensity by 1.5 times compared to the minimum depth of cut $(0.007 \mathrm{~mm})$.

5) A higher value of the temperature of the rails during grinding process provides a smaller amount of the wear intensity of samples cut from these rails. The intensity of wear at a grinding temperature of $-60^{\circ} \mathrm{C}$ is approximately 3 times higher than at temperatures of $40-80^{\circ} \mathrm{C}$. A similar pattern is typical for all values of depth of cut.

6) The dependence of the grinding wheel speed during rails grinding on the wear intensity at a treatment grinding depth of cut of $0.007 \mathrm{~mm}$ was established. The lowest wear intensity is at the minimum $(30 \mathrm{~m} / \mathrm{s})$ and the maximum $(40 \mathrm{~m} / \mathrm{s})$ grinding wheel speed. The wear intensity is the maximum (2.5-3 times higher) at grinding wheel speeds of $35-$ $40 \mathrm{~m} / \mathrm{min}$.

\section{Acknowledgements}

All authors acknowledge the financial support provided by the Deutsche Forschungsgemeinschaft (DFG). The presented results are part of the DFG-project Uh 100/203-1.

\section{References}

1. Рейки звичайні для залізниць широкої колії. Загальні технічні умови. ДСТУ 4344:2004. - [Чинний від 2005-10-01]. - К.: Держспоживстандарт України 2004. IX. - 28 с.

2. Railway applications - Track - Rail - Part 1: Vignole railway rails $46 \mathrm{~kg} / \mathrm{m}$ and above. (Залізниці-Колія-Рейки. Частина 1: Рейки Віньоля 46 кг/м і більше) EN 13674-1:2011. - [Чинний від 2011-02-09].

3. Zhang S. Effects of grinding passes and direction on material removal behaviors in the rail grinding process / S. Zhang, K. Zhou, H. Ding, J. Guo, O. Liu, W. Wang // Materials. - 2018. - №11 - C. 1 - 16. https://doi.org/10.3390/ma11112293.

4. Liu Y.M. Analytical modeling of grinding process in rail profile correction considering grinding pattern / Y.M. Liu, T.Y. Yang, Z. He, J.Y. Li // Arch. Civ. Mech. Eng. - 2018 - №18. - C. $669-678$. https://doi.org/10.1016/j.acme.2017.10.009.

5. Gu K.K. Analysis on the effects of rotational speed of grinding stone on removal behavior of rail material / K.K. Gu, Q. Lin, W.J. Wang, H.Y. Wang, J. Guo, O.Y. Liu, M.H. Zhu // Wear. - 2015. - №342-343. - C. 52 - 59. 
https://doi.org/10.1016/j.wear.2015.08.008.

6. Uhlmann E. Influence of rail grinding process parameters on rail surface roughness and surface layer hardness / E. Uhlmann, P. Lypovka, L. Hochschild, N. Schröer // Wear. - 2016. - №366-367. - C. 287 - 293.

https://doi.org/10.1016/j.wear.2016.03.023.

7. Zhe H. Investigating the effects of contact pressure on rail material abrasive belt grinding performance / H. Zhe, L. Jianyong, L. Yueming, N. Meng, F. Wengang // The International Journal of Advanced Manufacturing Technology. - 2017. - №93(1-4). - C. 779 - 786.

8. Uhlmann E. Influence of railway-track grinding on the track material condition and tribological behavior / E. Uhlmann, M. Bobyr, Y. Borodiy, P. Lypovka, J. Thalau, P. Protsenko // Advanced Materials Letters. - 2019. - №10(7). - C 449 - 454.

9. Steenbergen M. Rolling contact fatigue in relation to rail grinding // Wear. - 2016. - №356-357. - C. 110 - 121. https://doi.org/10.1016/j.wear.2016.03.015.

10. Матафонов А.В. Технологическое обеспечение качества поверхности рельсов при шлифовании в условиях железнодорожного пути / А.В. Матафонов, А.Н. Пыко, А.С. Ильиных // Вестник ЮУрГУ. Серия «Машиностроение». - 2015. - том 15, №1 . - С. 80 - 92.

11. Meier-Hirmer C., Pouligny Ph. Impact of preventive grinding on maintenance costs and determination of an optimal grinding cycle. Safety, Reliability and Risk Analysis: Theory, Methods and Applications: Proceeding of the European Safety and Reliability Conference, ESREL 2008, and $17^{\text {th }}$ SRA-Europe, 22-25 вересня 2008 р. Валенсія: CRC Press, 2008. - №1. - C. $3183-3189$.

12. Kuffa M. A new grinding strategy to improve the acoustic properties of railway tracks / M. Kuffa, D. Ziegler, T. Peter, F. Kuster, K. Wegener // Proceedings of the Institution of Mechanical Engineers. Part F: Journal of Rail and Rapid Transit. - 2018. - vol. 232, no.1. - C. 214 - 221. https://doi.org/10.1177/0954409716664935.

13. Цибульський В.А. Оптимизация свойств материалов ходовых колес мостовых кранов с целью повышения их долговечности: автореф. дис. канд. техн. наук: спец. 05.02.01 "Материаловедение в машиностроении" / Харківський національний автомобільно-дорожний університет. - Х. : 1996. -25 с.

14. Ямпольский Г.Я. Исследование абразивного износа элементов пар трения качения / Г.Я. Ямпольский, И.В. Крагельский - Москва: изд. "Наука", 1973. - 64 с.

15. Методические указания "Обеспечение износостойкости изделий. Метод экспериментальной оценки пластичности поверхностных слоев деталей машин”. РД 50-460-84 / Исп. И.В. Южаков, Г.Я. Ямпольский - Москва: Министерством высшего и среднего специального образования УССР, 1984. - 14 с.

16. Королюк В.С. Справочник по теории вероятностей и математической статистике / В.С. Королюк, Н.И. Портенко, А.В. Скороход, М. : Наука, 1985. - $640 \mathrm{c}$.

\title{
Дослідження зносостійкості контактної поверхні рейки в залежності від процесу їі шліфування
}

\author{
М. І. Бобир, Ю. П. Бородій, П. Ю. Проценко, Е. Ульман, Я. Талау, П. Липовка
}

Проблематика. Тривалі механічні навантаження на рейку під час ї̈ контакту з колесом призводять до накопичення залишкових напружень у поверхневих шарах рейки, внаслідок чого виникають швидкозростаючі втомні тріщини. Крім того, взаємодія колеса і рейки призводить до мікро- $і$ макроковзання під час їх контакту, абразивного зношування, а також пластичної деформачії рейки. Шліфування рейок - це спосіб їх ремонту, за допомогою якого видаляють дефектні шари матеріалу з поверхні рейок, забезпечують необхідну точність їх розмірів, форми та якості поверхні.

Мета дослідження. Дослідити вплив иліфування на трибологічні властивості поверхні рейки, а також встановити оптимальні параметри процесу шліфування для забезпечення найкращої зносостійкості поверхні рейки.

Методика реалізації. Дослідження зношування та контактного пошкодження поверхонь зразків, вирізаних із шліфованих рейок, проводилися на машині тертя М-22М. Дослідження здійснювались шляхом сухого тертя зразка (вирізаний з рейки) із контрзразком з матеріалу, що використовується при виготовленні залізничних коліс, протягом 1 години при иьому шлях тертя складав - 3,60 км. Зразки зважувались на вагах ВЛР-200 до та після виконання дослідження на машині тертя. $B$ результаті для кожного зразка було визначено величину масового зношування.

Результати дослідження. На основі результатів проведених трибологічних досліджень були побудовані графічні залежності інтенсивності зночування від твердості поверхонь зразків та гістограми, щяо показують вплив параметрів прочесу шліфування на величину інтенсивності зношування зразків. Основними параметрами процесу шліфування, які досліджувалися в роботі, є: температура рейки, припуск на обробку, лінійна швидкість шліфувального колеса.

Висновки. На основі проаналізованих експериментальних даних отримано емпіричну залежність між припуском на обробку, величиною поверхневої твердості зразка та інтенсивністю його зношування. Встановлено характер впливу параметрів процесу шліфування (температура рейки, припуск на обробку, лінійна швидкість шліфувального колеса) на зносостійкість поверхні рейки. Найбільш оптимальними величинами параметрів прочесу, щзо забезпечать більшу зносостійкість поверхні рейки, $\epsilon$ : припуск на обробку - 0,007 мм, лінійна швидкість шліфувального круга - $30 \mathrm{M} / \mathrm{c}$, температура - $20^{\circ} \mathrm{C}$ (обробку рейок краще вести в теплий період року). Результати роботи можуть знайти практичне застосування на залізничному транспорті при проведенні ремонту рейок иляхом шліфування.

Ключові слова: шліфування рейок; інтенсивність зношування; поверхнева твердість; трибологічні властивості.

\section{Исследование износостойкости контактной поверхности рельса в зависимости от процесса его шлифования}

\section{Н. И. Бобырь, Ю. П. Бородий, П. Ю. Проценко, Э. Ульман, Я. Талау, П. Липовка}

Проблематика. Длительные механические нагрузки на рельс при его контакте с колесом приводят к накоплению остаточных напряжений в поверхностных слоях рельса, в результате чего возникают быстрорастущие усталостные 
трещины. Кроме того, взаимодействие колеса и рельса приводит к микро- и макропроскальзыванию во время их контакта, абразивному износу, а также деформащии рельса. Шлифование рельсов - это способ их ремонта, с помощью которого удаляют дефектные слои материала с поверхности рельсов, обеспечивают необходимую точность их размеров, формы и качества поверхности.

Цель исследования. Исследовать влияние шлифования на трибологические свойства поверхности рельса, а также установить оптимальные параметры процесса шлифования для обеспечения лучшей износостойкости поверхности рельса. Методика реализации. Исследование износа и контактного повреждения поверхностей образцов, вырезанных из шлифованных рельсов, проводились на машине трения М-22М. Исследования осуществлялись путем сухого трения образиа (вырезанный из рельса) с контробразиом из материала, используемого при изготовлении железнодорожных колес, в течение 1 часа при этом путь трения составлял - 3,60 км. Образиы взвешивались на весах ВЛР-200 до и после выполнения исследования на машине трения. В результате для каждого образиа было определено величину массового износа.

Результаты исследования. На основе результатов проведенных трибологических исследований были построены графические зависимости интенсивности износа от твердости поверхностей образцов и гистограммы, показывающие влияние параметров процесса шлифования на величину интенсивности износа образцов. Основными параметрами процесса шлифования, которые исследовались в работе, являются: температура рельсы, припуск на обработку, линейная скорость шлифовального колеса.

Выводы. На основе проанализированных экспериментальных данных получено эмпирическую зависимость между припуском на обработку, величиной поверхностной твердости образиа и интенсивностью его износа. Установлен характер влияния параметров проиесса шлифования (температура рельсы, припуск на обработку, линейная скорость шлифовального колеса) на износостойкость поверхности рельса. Наиболее оптимальными величинами параметров процесса, которые обеспечат большую износостойкость поверхности рельса, являются: припуск на обработку - 0,007 мм, линейная скорость шлифовального круга - $30 \mathrm{M} / \mathrm{c}$, температура - 20 ${ }^{\circ} \mathrm{C}$ (обработку рельсов лучше вести в тепльй период года). Результаты работы могут найти практическое применение на железнодорожном транспорте при проведении ремонта рельсов путем илифования.

Ключевые слова: илифование рельсов; интенсивность изнашивания; поверхностная твердость; трибологические свойства.

\section{References}

1. National Standard of Ukraine (2004), DSTU 4344:2004 Reiky zvychaini dlia zaliznyts shyrokoi kolii. Zahalni tekhnichni umovy [Rails are common to wide gauge railways. General specifications], DSSU, Kyiv, Ukraine.

2. The European Standard (2011), EN 13674-1:2011, Railway applications - Track - Rail - Part 1: Vignole railway rails $46 \mathrm{~kg} / \mathrm{m}$ and above, European Committee for Standardization, Brussels, Belgium

3. Zhang, S., Zhou, K., Ding, H., Guo, J., Liu, O. and Wang, W. (2018), "Effects of grinding passes and direction on material removal behaviors in the rail grinding process", Materials, vol. 11, pp. 1 - 16. https://doi.org/10.3390/ma11112293

4. Liu, Y.M., Yang, T.Y., He, Z. and Li, J.Y. (2018), "Analytical modeling of grinding process in rail profile correction considering grinding pattern", Arch. Civ. Mech. Eng., vol. 18, pp. 669-678. https://doi.org/10.1016/j.acme.2017.10.009

5. Gu, K.K., Lin, Q., Wang, W.J., Wang, H.Y., Guo, J., Liu, O.Y. and Zhu, M.H., (2015), "Analysis on the effects of rotational speed of grinding stone on removal behavior of rail material", Wear, vol. $342-343$, pp. 52 - 59. https://doi.org/10.1016/j.wear.2015.08.008

6. Uhlmann, E., Lypovka, P., Hochschild, L. and Schröer, N., (2016), "Influence of rail grinding process parameters on rail surface roughness and surface layer hardness", Wear, vol. 366 - 367, pp. 287 - 293. https://doi.org/10.1016/j.wear.2016.03.023

7. Zhe, H., Jianyong, L., Yueming, L., Meng, N. and Wengang, F., (2017), "Investigating the effects of contact pressure on rail material abrasive belt grinding performance", The International Journal of Advanced Manufacturing Technology, vol. 93(1-4), pp. 779 - 786.

8. Uhlmann, E., Bobyr, M., Borodiy, Y., Lypovka, P., Thalau, J. and Protsenko, P. (2019), "Influence of railway-track grinding on the track material condition and tribological behavior", Advanced Materials Letters, vol. 10, no. 7, pp. $449-454$

9. Steenbergen, M. (2016), "Rolling contact fatigue in relation to rail grinding", Wear, vol. 356-357, pp. 110 - 121. https://doi.org/10.1016/j.wear.2016.03.015

10. Matafonov, A.V., Pyiko, A.N. and Ilinyih, A.S. (2015), "Tehnologicheskoe obespechenie kachestva poverhnosti relsov pri shlifovanii v usloviyah zheleznodorozhnogo puti” [Technological support for the quality of the surface of rails during grinding in a railway], Vestnik YuUrGU. Seriya «Mashinostroenie», vol. 15, no. 1, pp. 80 - 92.

11. Meier-Hirmer, C. and Pouligny, Ph. (2008), "Impact of preventive grinding on maintenance costs and determination of an optimal grinding cycle", Safety, Reliability and Risk Analysis: Theory, Methods and Applications, Proceeding of the European Safety and Reliability Conference, ESREL 2008, and 17 $7^{\text {th }}$ SRA-Europe, Valencia, Spain September, $22-25$, 2008, vol. 1, pp. $3183-3189$.

12. Kuffa, M., Ziegler, D., Peter, T., Kuster, F. and Wegener, K. (2018), "A new grinding strategy to improve the acoustic properties of railway tracks", Proceedings of the Institution of Mechanical Engineers. Part F: Journal of Rail and Rapid Transit, vol. 232, no. 1, pp. 214 - 221. https://doi.org/10.1177/0954409716664935

13. Tsibulskiy, V.A. (1996), "Optimization of material properties of bridge cranes running wheels in order to increase their durability", Abstract of Ph.D. dissertation, Kharkov National Automobile and Highway University, Kharkov, Ukraine

14. Yampolskiy, G.Ya. and Kragelskiy, I.V. (1973), Issledovanie abrazivnogo iznosa elementov par treniya kacheniya [Study of abrasive wear of elements of rolling friction pairs], Nauka, Moscow, Russia.

15. Yuzhakov, I.V. and Yampolsky, G.Ya. (1984), "Ensuring wear resistance of products. The method of experimental assessment of the plasticity of the surface layers of machine parts", Ministry of Higher and Secondary Special Education of the Ukrainian SSR, Moscow, Russia.

16. Korolyuk, V.S., Portenko, N.I. and Skorokhod, A.V. (1985), Spravochnik po teorii veroyatnostey i matematicheskoy statistike [Handbook of probability theory and mathematical statistics], Nauka, Moscow, Russia. 